\title{
状態フィードバック $H^{\infty}$ 制御理論を用いた アンチワインドァップコントローラの設計と実装
}

\author{
非正員 渡辺亮 (石川島播磨重工業) 非正員 松井 章之(新日本慗鉄) 正員 内田 健康 (早稻田大学)
}

\author{
Design and Implementation of Anti-Windup Controller Based on \\ State Feedback $H^{\infty}$ Control Theory \\ Ryo Watanabe, Non-Member(IHI) Akiyuki Matui, Non-Member(Nippon Steel) \\ Kenko Uchida, Member(Waseda University)
}

\begin{abstract}
In the control of actual plant, there commonly exits a constraint on the control input caused by mechanical constraint on the actuator or to protect the plant. This constraint usually exerts adverse effect on control performance called windup phenomenon. Anti-windup technique is known as one of the most effective techniques to prevent such windup phenomenon.

In this paper, we propose a new design of anti-windup controller based on state feedback $H^{\infty}$ control theory. This design consists of representation of anti-windup controller that includes a free parameter and decision of the free parameter by using state feedback $H^{\infty}$ control theory. Then, we also discuss the problem on discretization of anti-windup controller in implementation. In numerical case study, we demonstrate the performance of proposed anti-windup controller by computer simulation.
\end{abstract}

キーワード：ワインドアップ，制御入力に対する制限，状龍つィードバック $H^{\infty}$ 制御, 左既約分解

\section{1、まえがき}

実際の制御系では、アクチユエータの物理的な制約や制 御対象の保護の観点から，制御入力に対して何らかの制限 (飽和要素, レート制限等)が設けられていることが多い. 制御入力に対する制限が存在しないものとして設計された コントローラを直接このような制御系に適用した場合，ワ インドアップ [16] と呼ばれるステップ応答等が大きくオー バーシュートする現象がしばしば発生することが知られて いる。

ワインドアップの原因が制御入力に対する制限にあるこ とから，その抑制対するアプローチとして次の二つを考 えることができる．1つは，制御入力に対する制限をあら かじ考慮に入れ，その制限在越えないコントローラを設 計するというアプローチである。このような設計法として， コントローラの設計問題を制御入力に上（下）限を設けた 最適制御問題に帰着させる手法がある。一般にこの問題に 対する解は, 複雑なバンバン型のフィードバックコントロー ラとなることが多く，解を得るために複雑な計算が必要と される。また，制御対象の不確かさに敏感であることが多 いため，あまり実用的であるとは言えないもう1つは，ま ず制限が存在しないものとしてコントローラを設計，ての 㣪ワインドアップを抑制するフィードバックループやロジッ クを付け加えるというアプローチである。このアプローチ
の代表的なものに，アンチワインドアップ手法 [5][2] があ る。この手法は，コントローラのアンチワインドアップ化 が比較的容易であること、また，制御对象の不確かさを考 慮に入れた設計も可能であることから，実用的であり広く 適用されている。

アンチワインドアッブ手法は, 当初積分器を用いた場合 に生ずるワインドアップの抑制という制御技術著の試みか ら始まり，その嗦幾人かの研究者によって，ワインドアッ プを異なる観点から捉えたいくつかの方法 [1][5][6][9][16]が 提案された。また，多变数制御系の設計理論の枠組におけ る安定性や性能の解析を視野に入れた研究 [2][3][5][18] も始 まっている、しかしながら，これまでに提案されている各 手法は，制御対象や制限の種類に応じた限界を有すること から，より優れたアンチワインドアップコントローラが，之 してより系統的なアンチワインドアップコントローラの設 計法が望まれている。

本稿では, Campo, Morariらによって提唱されたGeneral AWBT Scheme[2] に基づくアンチワインドアップコント ローラの新しい設計法を提案する。この設計法は, 左既約 分解に基ついた、フリーパラメータを持つアンチワインド アップコントローラの実現と, 状態フィードバック $H^{\infty}$ 制 御理論を用いたフリーパラメータの設計から構成されてい る、また，アンチワインドアップコントローラの実装に伴っ て生ずる，離散化の問題点を明らかにし，この問題を回避 する実装手順を与える。数值例では，与えられた制御対象， 
コントローラ，および制御入力に対する制限に対して実際 にアンチワインドアップコントローラを設計，その性能を シミュレーションにより検証する.

\section{2.ワインドァップ現象}

$<2 \cdot 1>$ 制御入力に対する制限一般にコントローラ の設計は図 1 に示される枠組でおこなわれるが，実際の制 御対象はほとんどの場合，アクチュエーターの物理的な制 限 (飽和特性やレート制限) や，制御対象の安全な運用を目 的とした制御入力に対する制限を有する，多くの場合，こ れらの制限は，図 2 に示されるような制御入力に対する制 限 $N L_{u}$ として表現される。

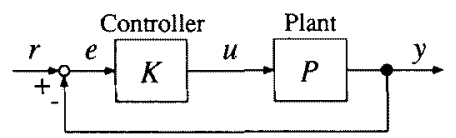

図 1 制御系設計の枠組

Fig.1. Configuration of Controller design

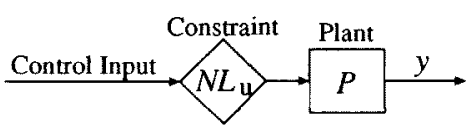

図 2 制御入力に対する制限

Fig.2. Constraint on the Control Input

一般に，制限 $N L_{u}$ を越える制御入力の印加は制御対象を 損なう恐れがあるため，実際の制御では，図 3 に示される ようにあらかじめコントローラの出力に対する制限 $N L を$ 設けることで，制御入力に対する制限 $N L_{u}$ に対応している.

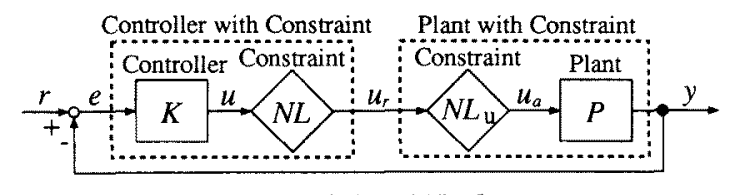

図 3 実際の制御系

Fig.3. Actual Control System

図 3 において, $u$ はコントローラの出力を, $u_{r}$ はコント ローラの出力に対する制限 $N L$ の出力を表するのとする. また， $u_{a}$ は制御入力に対する制限 $N L_{u}$ の出力である制御対 象への入力を表すものとする.

この場合，図 3 の制御系に招けるコントローラの出力に 対する制限 $N L$ を， $u_{r}=u_{a}$ が常に成立するように設定(例 えば $N L_{u}$ が飽和要素の場合， $N L$ を飽和要素に設定)する ことで，図3の制御系を図4の制御系と見なすことができ る、そこで，以降では図 4 の制御系で議論を進めることに する。

$<2 \cdot 2>$ ワインドアップ現象 図1の染組で設計された コントローラを図 4 の制御系に直接適用した場合, 制御量 のステップ応答等が $N L$ が存在しない場合と比べて大きく オーバーシュートする，ワインドアップ [5][16]と呼ばれる

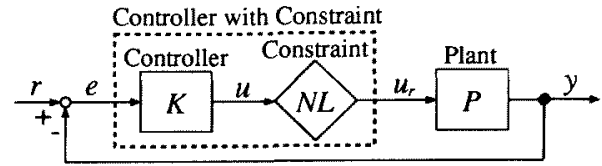

図 4 等価な制御系

Fig.4. Equivalent Control System

現象を生ずることがある、ワインドアップ現象を生ずる制 御采の例を次に示す。

例 2.1[18] 制御対象 $P$, およびコントローラKが次で 与えられているものとする。

$$
\begin{aligned}
& P= \frac{16}{s^{2}+1.6 s+16}, \\
& K=\frac{3.870 s^{4}+13.93 s^{3}+171.1 s^{2}}{s^{5}+11.44 s^{4}+100.5 s^{3}+355.8 s^{2}} \\
& \frac{+278.7 s+1548}{+973.9 s+1.169} .
\end{aligned}
$$

また，制御入力に対する制限 $N L$ は以下を考える。

$$
u_{r}=\left\{\begin{array}{cc}
y+2.1, & u>y+2.1 \\
u, & u \leq y+2.1 .
\end{array}\right.
$$

制御対象の出力に応じて定まるこのような制限は，ジェット エンジンの制御 [13] 等でしばしば見ることができる. $r=0$ から $r=13$ のステップ指令值に対する, 図1の制御系 $(N L$ が存在しない場合), および図 4 の制御系 ( $N L$ が存在する 場合) の応答を図 5 に示す. 図 5 において上が制御対象 $P$ の出力, 下が制御対象 $P$ 人の入力を表す。
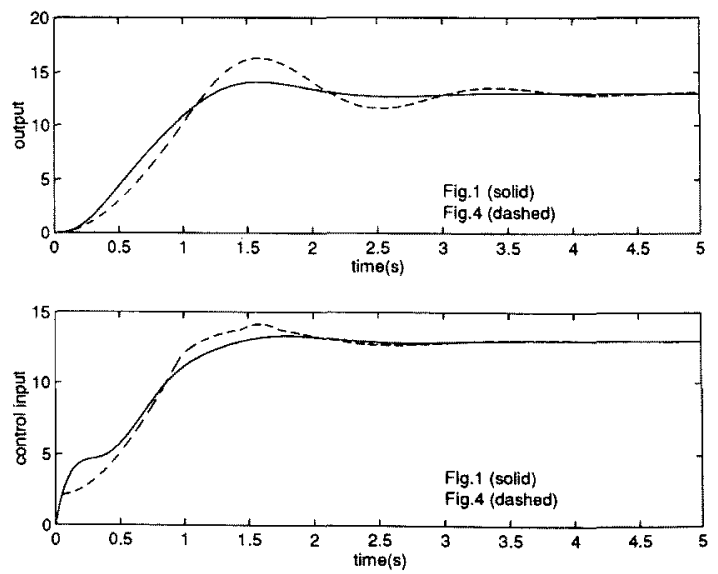

図 5 ステップ応答

Fig.5. Step responses

この例に見られるように，ワインドアップ現象は実際の 制御において制御性能を低下させる大きな要因の一つであ る.ワインドアップ現象に関する共通の認識として, 制御 入力に対する制限に起因するコントローラの出力と制御入 力の不一致がその原因であること，コントローラが積分要 
素等の収束の遅いダイナミクスを有する場合に発生し易い こと等があげられる. また，現時点で与えられているワイ ンドアップ現象に関する記述は，安定性の観点からの解釈 (例之ば文献 [6]) と，特定のコントローラと特定の飽和要素 に対する定性的な説明 (例之ば文献 [16]) がほとんどで，何 をもってワインドアップと呼ぶかという制御理論的な定義 は存在しないのが現状である。

\section{3. アンチワインドアップコントローラ}

本節では, Campo, Morari らによって提唱された General AWBT Scheme[2] に基づくアンチワインドアップコント ローラについて述べる。

$<3 \cdot 1>$ 左既約分解 [11] コントローラ $K$ の最小䒠現 が以下で与えられているとする.

$$
K=\left[\begin{array}{l|l}
A & B \\
\hline C & D
\end{array}\right] .
$$

(1)式が最小実現であることから， $\left(A^{\prime}, C^{\prime}\right)$ は可制御となる. これより， $A^{\prime}-C^{\prime} F^{\prime}$ 安定とする状態フィードバックゲイ ン $F^{\prime}$ が存在, この $F$ を用いてコントローラ $K$ を二つの安定 なシステムの積として以下のように分解することができる.

$$
\begin{aligned}
K & =\tilde{M}^{-1} \tilde{N} \\
& =\left[\begin{array}{c|c}
A-F C & F \\
\hline-C & I
\end{array}\right]^{-1}\left[\begin{array}{c|c}
A-F C & B-F D \\
\hline C & D
\end{array}\right] .
\end{aligned}
$$

(2) 式の表現を，Kの左既約分解表現という，一方， $\tilde{M}$ か

$$
\begin{aligned}
\hat{M} & =I-\tilde{R}, \\
\tilde{R} & =\left[\begin{array}{c|c}
A-F C & F \\
\hline C & 0
\end{array}\right] .
\end{aligned}
$$

と表されることから，Kの左既約分解表現は図 6 のブロッ ク線図で与えられる。

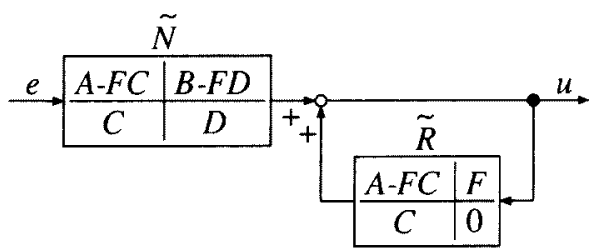

図 6 左既約分解

Fig.6. Left Coprime Factorization

$<3 \cdot 2>$ アンチワインドアップコントローラ 図6に示 される左既䄪分解で与えられたコントローラKに対し，コ ントローラの出力に対する制限 $N L$ を図 7 に示されるよう に尽を含むループへ挿入，これにより制御入力に対する制 限 $N L_{u}$ に対応することを考える.

ここで, $N L$ がコントローラの出力に対する制限であるこ とから，図 7 に示されるコントローラを構成することが実 祭に可能であることに注意する，uが $N L$ の影響を受けな い場合 $(N L=I$ と見なせる場合)，図 7 は $K$ と等価である.

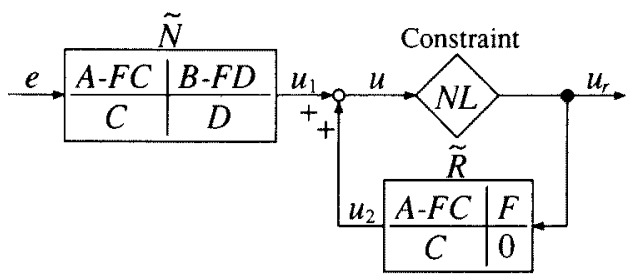

図 7 アンチワインドアップコントローラ

Fig7. Anti-Windup Controller

図 7 の形で $N L$ を含むコントローラと図 4 の形で $N L$ を 含むコントローラ(図 4の点線で囲まれた部分) の違いを， $K か ゙$ 積分器, $N L$ が飽和要素, コントローラへの入力 $\epsilon$ が 一定值の場合を例にとって考えてみる。このとき，図4で は $u$ が増加し続けるのに対し, 図 7 では $A-F C$ が安定で あることから，uはある一定の値を超えることはない、ま た，Fの選び方によっては， $u$ と $u_{r}$ をほは同一の值に保つ ことが可能であり，このことは，フリーパラメータFによ るワインドアップ抑制の可能性を示唆している. 以降では, フリーパラメータFをアンチワインドアップパラメータと 呼ぶ.

なお， $K_{F}$ を次で定義することにより，図7と等価な表現 として図 8 を得る。

$$
K_{F}=\left[\begin{array}{c|cc}
A-F C & B-F D & F \\
\hline C & D & 0
\end{array}\right] .
$$

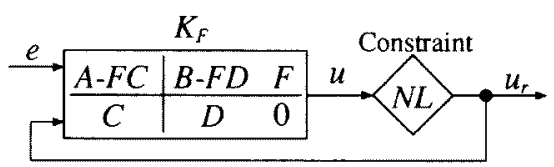

図 8 等価な表現

Fig.8. Equivalent Representation

(注意 3.1) Campoらが General AWBT Scheme とし て提案したアンチワインドアップコントローラの状態変数 表現は次で与えられる。

$$
\begin{aligned}
\dot{x}_{c} & =A x_{c}+B e+z_{1} \\
u & =C x_{c}+D \epsilon+z_{2} \\
z_{1} & =\Lambda_{1}\left(u_{r}-u\right) \\
z_{2} & =\Lambda_{2}\left(u_{r}-u\right)
\end{aligned}
$$

ここで， $\Lambda_{1}, \Lambda_{2}$ はフリーパラメータである．本節で与えた アンチワインドアップコントローラは $\Lambda_{1}=F, \Lambda_{2}=0$ の 場合に相当する。な押，文献 [2]は，フリーパラメー夕 $\Lambda_{1}$, $\Lambda_{2}$ の決定に関していくつかの指針を示しているだけで，以 降で提案するような，その具体的な設計法やアンチワイン ドアップコントローラの実装に関する問題については触れ ていない.

\section{4. 設計と実装}

< $4 \cdot 1>$ アンチワインドアップコントローラの設計＼cjkstart何 らかの理論的な正当性を有するアンチワインドアップコン 
トローラの設計法を提案するためにはワインドアップの理 諭的な定式化が必要とされるが，現時点では 2 節で述べた ように

・制御入力に対する制限に起因するコントローラの出力 と制御入力の不一致が原因である

・コントローラが積分要素等の収束の遅いダイナミクス を有する場合に発生し易い

という共通認識と,

- 安定性の観点からの解釈

・特定のコントローラと特定の飽和要素に対する定性的 な説明

が与えられているだけで，何をもってワインドアップと呼 ふかと言う制御理論的な定義は存在しない。しかしながら， ワインドアップ現象は実際の制御において制御性能を低下 させる大きな要因の一つであり，制御理論的に十分にその 現象が説明できない現状では，直観的な解釈に基づく方法 であってもワインドアップの挪制に有效な設計法を与える ことには意味があると考えられる。図 7 の構造に着目する と，直観的にではあるが，アンチワインドアップコントロー ラの設計に関して，次の二つの方向を考えることができる， 一つは, フリーパラメータを用いてアンチワインドアップ コントローラのダイナミクスを速く寸る，という考え方に 基づく方向である。これは，ワインドアップがコントローラ に積分要素等の収束の遅いダイナミタスが存在する場合に 多く発生することを鑑みた設計方針であるといえる。本稿 のアンチワインドアップコントローラに関していえば，こ れは，A-FCO固有值が複素平面上でより左になるよう にアンチワインドアップパラメータ Fを設計することを意 味する。しかしながら，A-FCの固有値を複素平面上でよ り左になるように配置しても，後の数值例でも示寸ように ワインドアップが十分抑制されない場合が存在する。

もう一つは, 制限 $N L$ の入力 $u$ と出力 $u_{r}$ が恒にほほ同じ 值をとるようフリーパラメータを選尔方向である．これは， ワインドアップが，制御入力に対する制限に起因するコン トローラの出力と制御入力の不一致を原因とすることを鑑 みた設計法である。本稿では，この考方方に基づいたアン チワインドアップパラメータの設計法を提案する。

図7に示されるアンチワインドアップコントローラを含む 制御系がサーボ系で, 平衡状態では $u_{r}(\infty)=u(\infty)$ であると 仮定寸る.この制御系の平衡状態に扔引る偏差は $e(\infty)=0$, これより $u_{1}(\infty)=0$ を得る. 従って

$$
\begin{aligned}
u_{r}(\infty) & =u(\infty)=u_{1}(\infty)+u_{2}(\infty) \\
& =\tilde{R}(0) u_{r}(\infty)
\end{aligned}
$$

この式は,アンチワインドアップパラメータ Fの選び方に よらず

$$
\tilde{R}(0)=I
$$

であることを示している，従って，e(t)と $u_{r}(t)$ が一定值， $e(t)=\bar{\epsilon}, u_{r}(t)=\bar{u}_{r}$ の場合, $u(\infty)$ は次で与えられる.

$$
\begin{aligned}
u(\infty) & =\tilde{N}(0) \cdot \bar{\epsilon}+\tilde{R}(0) \bar{u}_{r} \\
& =\tilde{N}(0) \cdot \bar{\epsilon}+\bar{u}_{r} .
\end{aligned}
$$

これより次をえる。

$$
u(\infty)-\bar{u}_{r}=\tilde{N}(0) \cdot \bar{\epsilon} .
$$

この式は， $\tilde{N} か ゙ e か ら ~ u-u_{r}$ へのゲインに深く関係してい ることを示唆しており，このことから，Nのゲインがあら 中る周波数で小さくなるようにアンチワインドアップパラ メータ Fを選べば，制御系はよりアンチワインドアップ化 されると考えられる。

Nの大きさの尺度として $H_{\infty}$ ノルムを考えた場合，問題 は“与えられた $\gamma>0$ に対し， Nが次を渵たすような $F$ を 求めよ”と記述される.

$$
\|\tilde{N}\|_{\infty}<\gamma .
$$

$\|\tilde{N}\|_{\infty}=\left\|\tilde{N}^{\prime}\right\|_{\infty}$ より，アンチワインドアップパラメータ $F$ の設計問題は, 次の状態フィードバック $H^{\infty}$ 制御問題に帰 着される。

連続時間コントローラんの最小共現が，(1) 式で与えら れているものとする。このとき，与えられた $\gamma>0$ ，および 次の一般化プラント

$$
\begin{aligned}
& \dot{x}=A^{\prime} x+C^{\prime} w+C^{\prime} u, \\
& z=B^{\prime} x+D^{\prime} w+D^{\prime} u,
\end{aligned}
$$

に対し，閉ループを内部安定化し

$$
\left\|T_{z \psi}\right\|_{\infty}<\gamma,
$$

を満たす状態つィードバック制御則

$$
u=-F^{\prime} x,
$$

を求めよこここで， $T_{z w}$ は閉ループ系に拈ける $z$ から $w$ への 伝達関数を表すものとする。なお， $T_{z w}=\tilde{N}$ である.

コントローラ $K$ が䈌密にプロパーな場合 ( $D=0$ の場合), アンチワインドアップパラメータ Fは，次のリカッチ方程式

$$
A P+P A^{\prime}-\frac{1}{\gamma^{2}} P C^{\prime} C P+B B^{\prime}+\delta I=0, \delta>0,
$$

の正定解Pによって次で与えられる。

$$
F^{\prime}=\frac{1}{\gamma^{2}} C P \text {. }
$$

$D \neq 0$ の場合，Zhou らのアルゴリズム [14] 等が適用可能 である.

（注意 4.1） ワインドアップの抑制に加え，NLを含む制 御系全体の安定性を保つことは，アンチワインドアッフココ ントローラが満たすべき最も重要な条件の一つである。本 稿で提案するアンチワインドアップコントローラに関し，一 つの十分条件が筆者の一人によって導かれている [17]. ま 
た，一般的には $\mu$ 解析 [4]によって安定性を調べることがで さる。

<4.2>アンチワインドアップコントローラの実装 コ ントローラは一般に連続時間で設計されるため，実装に際 しては何らかの形で触散化をおこなう必要がある。(3)式で 与えられる連絸時間アンチワインドアップコントローラ $K_{F}$ に対するサンプル時間 $T$, 零次ホールドによる離散化を

$$
K_{F d}=\left[\begin{array}{c|cc}
A_{F d} & B_{F d 1} & B_{F d 2} \\
\hline C & D & 0
\end{array}\right],
$$

とすると，制御入力が制限の影響を受けない場合 $(N L=I$ と見なせる場合)， $K_{F d}$ は次の離散時間コントローラ $\tilde{K}_{d}$ と 等洒である。

$$
\tilde{K}_{d}=\left[\begin{array}{c|c}
A_{F d}+B_{F d 2} C & B_{F d 1}+B_{F d 2} D \\
\hline C & D
\end{array}\right] .
$$

ここで，上記の $\tilde{K}_{d}$ は，もとの連続時間コントローラKをサ ンプル時間 $T$, 零次ホールドで離散化した蜼散時間コント ローラ $K_{d}$ に対し， $\tilde{K}_{d}=K_{d}$ を満たす必要があることに注 意する。

4.1 節で提案したアンチワインドアップコントローラの設 計法では，性能指標子を小さく選ぶほど，よりワインドアッ

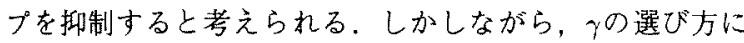
よっては，アンチワインドアップコントローラのシステム 行列 $A-F C$ が，離散化に捛けるサンプル周期よりもかな り速い固有値を有してしまい， $\tilde{K}_{d}$ と $K_{d}$ の周波数応答に大 きな違いを生ずる場合がある(数值例を参照)。このことは， アンチワインドアップコントローラによるワインドアップ 抑制と実装に伴う離散化との間に，トレードオフが存在す ることを示唆している.

この点を考慮したアンチワインドアップコントローラの 離散化手順を, 以下に示す。

（1）与えられたチに対し，4.1節の設計法に基づいてアンチ ワインドアップパラメータ $F$ を求める。

(2)（3)式で与えられる連続時間アンチワインドアップコン トローラ $K_{F}$ をサンプル時間 $T$, 零次ホールドで離散 化, 離散時間アンチワインドアップコントローラ $K_{F d}$ を求める。

(3) もとの連続時間コントローラ $K$ をサンプル時間 $T$ ，零 次ホールドで離散化した離散時間コントローラ $K_{d}$ と, (5)式より導かれる $\tilde{K}_{d}$ の周波数応答を比較する. $K_{d}=$ 和である場合は終了，そうでない場合， $\tilde{\gamma}>\gamma$ を選び (1) に戻る。

（注意 4.2） デジ夕ル制御装置への実装を考えた場合， 従来提案されているアンチワインドアップコントローラに ついても同様の問題が生ずると考えられる，その場合，上 記の手順と同様に，離散時間アンチワインドアップコント ローラのシステム行列の固有值を考慮しながら，フリーパ ラメータを設計する必要がある。

\section{5. 数值例}

本節では，前節で提案した設計法の有効性をシミュレー ションにより検証する。シミュレーションにおけるコント

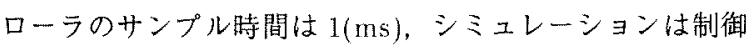
系がサンプル值系(コントローラが㜠散時間系, 制御対象 は連続時間系)であるものとしておこなった。

制御対象 $P$ ，コントローラ $K$ ，制御入力に対する制限 $N L$ ，および指令值は例 2.1 と同様とする。また，Kをサ ンプル時間 $1(\mathrm{~ms})$ ，零次ホールドで離散化した離散時間コ ントローラを $K_{d}$ とする。なお，アンチワインドアップパラ メータFの設計に必要な $H$ の最小実現は次を用いた。

$$
\begin{aligned}
A & =\left[\begin{array}{ccccc}
-11.44 & -100.5 & -355.8 & -973.9 & -1.169 \\
1 & 0 & 0 & 0 & 0 \\
0 & 1 & 0 & 0 & 0 \\
0 & 0 & 1 & 0 & 0 \\
0 & 0 & 0 & 1 & 0
\end{array}\right], \\
B & =\left[\begin{array}{lllll}
1 & 0 & 0 & 0 & 0
\end{array}\right]^{\prime}, \\
C & =\left[\begin{array}{lllll}
3.870 & 13.93 & 171.1 & 278.7 & 1548
\end{array}\right], \\
D & =0 .
\end{aligned}
$$

$<5 \cdot 1>$ ワインドァップの抑制 以下の $\gamma$ に対し，(4)式 に基づいてアンチワインドアップパラメータ $F$ を計算, 離 散時間アンチワインドアップコントローラ $K_{F d}$ を求めた。 なお，(4)式における反は， $\delta=1.000 \times 10^{-6}$ とした。

$$
\gamma=1.000 \times 10^{-1}, \quad \gamma=2.000 \times 10^{-2} .
$$

各行対する $F$ を表1に示す。

表 1 アンチワインドアップパラメータ

Table 1. Anti-Windup parameters

\begin{tabular}{c|r}
\hline \hline$\gamma$ & \multicolumn{1}{|c}{$F$} \\
\hline & $1.714 \times 10^{+0}$ \\
$1.000 \times 10^{-1}$ & $-5.159 \times 10^{-2}$ \\
& $-6.695 \times 10^{-3}$ \\
& $1.607 \times 10^{-3}$ \\
& $1.915 \times 10^{-3}$ \\
\hline & $4.286 \times 10^{+1}$ \\
& $-1.290 \times 10^{+0}$ \\
$2.000 \times 10^{-2}$ & $-1.674 \times 10^{-1}$ \\
& $4.017 \times 10^{-2}$ \\
& $4.788 \times 10^{-2}$ \\
\hline
\end{tabular}

$N L$ が存在しない場合 (図 1 の制御柔でコントローラが $\left.K_{d}\right)$ ，アンチワインドアップコントローラを用いない場合 (图 4 の制御系でコントローラが $K_{d}$ )，および各離散時間ア ンチワインドアップコントローラを用いた場合の出力を図 9 に示す.

$<5 \cdot 2>$ 離散化の問題 ここでは，4.2節で考察した 嚁散化に伴う問題を検証する。そこで，(4)式に基づき， 


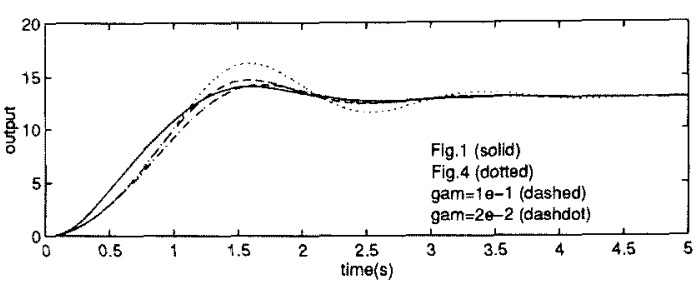

図 9 ステップ芯答

Fig. 9. Step Responses

$\gamma=1.000 \times 10^{-3}$ に対するアンチワインドアップパラメー 夕F計算，離散時間アンチワインドアップコントローラ $K_{F d}$ を求めた。なお，(4)式における反は， $\delta=1.000 \times 10^{-6}$ とした， $\gamma=1.000 \times 10^{-3}$ に対するアンチワインドアップ パラメータ Fを以下に示す。

$$
F=\left[\begin{array}{r}
8.886 \times 10^{+2} \\
-2.966 \times 10^{+1} \\
-3.235 \times 10^{+0} \\
8.181 \times 10^{-1} \\
9.537 \times 10^{-1}
\end{array}\right] .
$$

5.1 節の $\gamma$ ，および $\gamma=1.000 \times 10^{-3}$ に対する，A-FCの固 有值 $\rho(A-F C)$ を表 2 に示寺. 表 2 より, $\gamma=1.000 \times 10^{-3}$ では，A-FCがサンプル時間に比べてかなり速い固有值 を有していることがわかる。

表 2 アンチワインドアップコントローラの固有值

Table 2. Eigen Values of Anti-Windup Controllers

\begin{tabular}{c|c}
\hline \hline$\gamma$ & \multicolumn{1}{|c}{$\rho(A-F C)$} \\
\hline \multirow{1}{*}{$1.000 \times 10^{-1}$} & $-1.870 \pm 5.548 j$ \\
& $-1.677 \pm 3.573 j$ \\
& $-4.186 \times 10^{+1}$ \\
\hline \multirow{3}{*}{$2.000 \times 10^{-2}$} & $-1.811 \pm 5.560 j$ \\
& $-1.666 \pm 3.586 j$ \\
& $-2.091 \times 10^{+2}$ \\
\hline \multirow{3}{*}{$1.000 \times 10^{-3}$} & $-1.808 \pm 5.560 j$ \\
& $-1.666 \pm 3.587 j$ \\
& $-4.181 \times 10^{+3}$ \\
\hline
\end{tabular}

次に, 離散時間コントローラ $K_{d}$, および各子に対して (5) 式より導かれる $\tilde{K}_{d}$ のゲイン線図を图 10 に示す。図 10 より, $\gamma=1.000 \times 10^{-3}$ に対する $\tilde{K}_{d}$ のゲイン線図は，他に比べて 大きく異なっていることがわかる。

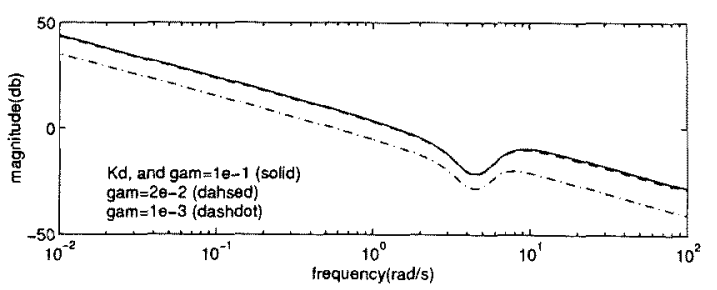

図 10 コントローラのゲイン線図

Fig. 10. Gain plots of Controller
最後に，NLが存在しない場合 (図 1 の制御系でコント ローラが $\left.K_{d}\right)$ ，拈よび各離散時間アンチワインドアッブコ ントローラを用いた場合の出力を図 11 に示す，図 11 より，

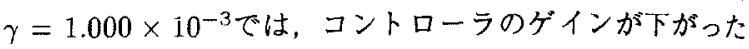
影響から応答がかなり遅くなっていることがわかる。

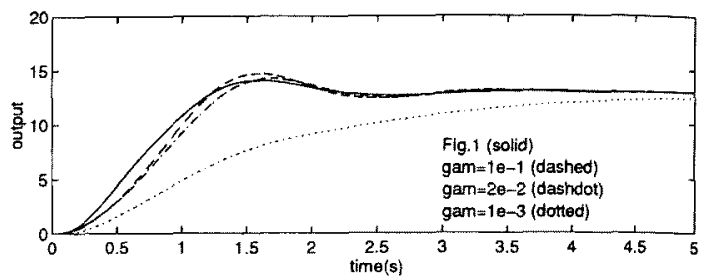

図 11 ステップ応答

Fig. 11. Step Responses

$\langle 5 \cdot 3\rangle$ 固有值との関係 $A-F C$ 固有值とワイン ドアップ抑制の関係を調べるために，A-FCの固有值が以 下の二通りとなるようにアンチワインドアップパラメータ Fを計算した。

$$
\begin{array}{llrrr}
\text { Case } 1 & : & -5 & -6 \pm j & -7 \pm j \\
\text { Case } 2 & : & -10 & -11 \pm j & -12 \pm j
\end{array}
$$

Case 1, Case 2 に対するFの值を表 3 に示す.

表 3 アンチワインドァップパラメータ

Table 3. Anti-Windup parameters

\begin{tabular}{c|r}
\hline & \multicolumn{1}{|c}{$F$} \\
\hline & $-8.898 \times 10^{+0}$ \\
& $-7.073 \times 10^{-1}$ \\
Case 1 & $4.849 \times 10^{-1}$ \\
& $-7.618 \times 10^{-2}$ \\
& $1.367 \times 10^{-3}$ \\
\hline & $-6.493 \times 10^{+1}$ \\
& $3.466 \times 10^{+1}$ \\
Case 2 & $-4.215 \times 10^{+0}$ \\
& $-7.188 \times 10^{-1}$ \\
& $4.746 \times 10^{-1}$ \\
\hline
\end{tabular}

$N L$ が存在しない場合 (図 1 の制御系でコントローラが $\left.K_{d}\right)$, アンチワインドアップコントローラを用いない場合 (図 4 の制御系でコントローラが $K_{d}$ )，拉よび各離散時間了 ンチワインドアップコントローラを用いた場合の出力を図 12 に示す. 図 12 より, Case 1 では多少ワインドアップが 抑制されているが, Case 2 は逆に出力の応答が悪化してい ることがわかる．このことは，複素平面上でより左になる ように $A-F C$ の固有值を単純に配置しても, 出力の応答 は改善されないことを示している。

\section{6.むすび}

本稿では, 状態フィードバック $H^{\infty}$ 制御理論に基づく、ア ンチワインドアップコントローラの新しい設計法を提案し た。また，実装に俘う離散化に扔ける問題点を明らかにし， それを考慮に入れた離散化手順を与えた。数值例では SISO 


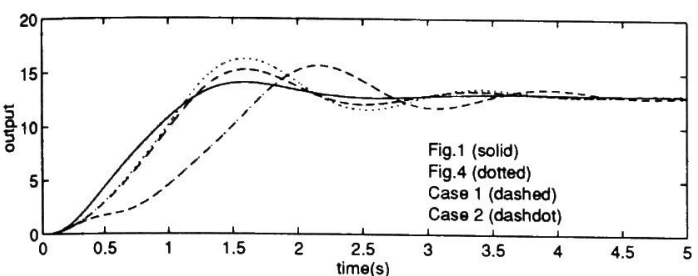

図 12 ステップ㐫答

Fig. 12. Step Responses

系のみを示したが, MIMO系についても，多くの場合十分 にワインドアップが抑制されることを確認している [17]. 本 稿で提案した方法は, 複数のコントローラの切替時に生ず るバンプ [5] を抑制する手段として用いることも可能であ る. 最後に, 本稿における手法を実機に適用し, 良好な結 果を得ていることを付け加えておく $[20]$.

(平成 8 年 2 月 13 日受付, 同 8 年 8 月 26 日再受付)

\section{参考文献}

[1] K.J.Åström, B.Wittenmark, Computer Controlled Systems, Printice-Hall,Inc. (1984)

[2] P.J.Campo, M.Morari, C.N.Nett, Multivariable AntiWindup and Bumpless Transfer : A General Theory, In Proc. 1989 ACC, 1706/1711 (1989)

[3] J.C.Doyle, R.S.Smith, D.F.Enns, Control of Plants with Input Saturation Nonlinearities, In Proc. 1987 ACC, 1034/1039 (1987)

[4] J.C.Doyle, A.Packard, Uncertain Multivariable Systems from a State Space Perspective, In Proc. 1987 ACC, 2147/2152 (1987)

[5] R.Hanus, M.Kinnaert, J.L.Henrotte, Conditioning Technique, a General Anti-Windup and Bumpless Transfer Method, Automatica, 23-6, 729/739 (1987)

[6] I.Horowitz, A Synthesis Theory for a Class of Saturation System, Int.J.Control, 38-1, 169/187 (1983)

[7] R.A.Hyde, K.Glover, Vstol Aircraft Flight Control System Design Using $\mathcal{H}_{\infty}$ Controllers and a Switching Strategy, In Proc. 1990 CDC, 2975/2980 (1990)

[8] P.Kapasouris, M.Athans, Design of Feedback Control Systems for Stable Plants with Saturating Actuators, In Proc. 1988 CDC, 469/479 (1988)

[9] M.Morari, E.Zafiriou, Robust Process Control, Printice-Hall,Inc. (1989)

[10] M.Morari, Some Control Problems in the Process Industries, In "Essays on Control : Perspectives in the Theory and its Applications", 55/76, Birkhäuser (1993)
[11] C.N.Nett, C.A.Jacobson, M.J.Balas, A Connection Between State-Space and Doubly Coprime Fractional Representations, IEEE Trans. on A.C., 29-9 , $831 / 832$ (1984)

[12] K.S.Walgama, J.Sternby, Inherent observer property in a class of anti-windup compensators, Int.J.Control, $52-3,705 / 724(1990)$

[13] R.Watanabe, M.Kurosaki, K.Uchida, M.Fujita, $H^{\infty}$ Control of Gasturbine Engines for Helicopters, In Proc. of American Control Conference, 787/790, San Francisco (1994)

[14] K.Zhou, P.P.Khargonekar, An algebraic Riccati equation approach to $H^{\infty}$ optimization, Systems \& Control letters, 11, 85/91 (1988)

[15] 川邊，北森，操作端の飽和による制御演算暴走を防ぐ制 御器構成法, 計測自動制御学会論文集, 29-7, 851/853 (1993)

[16] 須田, PID 制御, 朝倉書店 (1992)

[17] 松井, 左既䄪分解に基づく Anti-Windup コントローラ の設計, 早稲田大学理工学研究科平成 5 年度修士論文, (1994)

[18] 渡辺, 内田, 示村, 藤田, 制御入力が制限を受ける制御 系に対する Anti-Windup and Bumpless Transferの新 しい設計法, 計測自動制御学会論文集, 30-6, 660/668 (1994)

[19] 渡辺, 松井, 内田, 示村, 左既約分解に基づく Anti Windup コントローラの設計, 第 16 回 Dynamical System Thoery シンポジゥム予稿集, $57 / 62$, 神戸 (1993)

[20] 渡辺, 黑崎, 内田, 藤田, 示村, 燃料流量制御弁の状態 フィードバック $H^{\infty}$ 制御, 第 23 回制御理論シンポジウ 么予稿集, 刈谷 (1994)

[21] 和田, 佐伯, 行列不等式条件に基づくAnti-Windup コ ントローラの設計, 第 4 回計測自動制御学会中国支部 学術講演会論文集, 238/239, 岡山 (1995)

渡辺亮 （非正員）1989 年, 慶応義塾大学大学院修

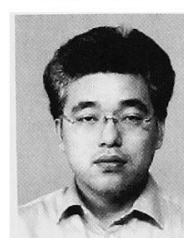
士課程修了. 95 年, 早稲田大学大学院博士 課程修了. 89 年, 石川島播磨重工業 (株) 入 社, 航空宇宙事業本部制御技術部に配属, 現 在に至る.ジェットエンジンのロバスト制御， およびゲインスケジューリングに関する研究 に従事. 博士 (工学). 計測自動制御学会, システム制御情報学会の会員. 


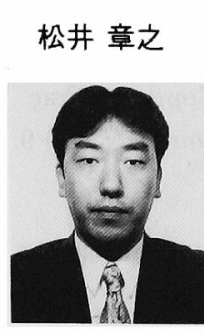

(非正員) 1994 年, 早稲田大学大学院修士 課程修了. 同年, 新日本製鉄（株）入社. 以 降八幡製鉄所において製鉄プラントの計測制 御に関する開発拉よび実機化に従事. 計測自 動制御学会の会員

内田 健康 （正員）1973 年, 早稲田大学修士課程修了. 76 年, 同大学博士課程修了. 83 年より, 早稲 田大学教授 (電気電子情報工学科), 現在に 至る、制御系の情報構造，ロバスト制御およ び推定などの研究に従事. 工学博士. 計測自 動制御学会, システム制御情報学会, IEEE などの会員. 